\title{
Comunicação e sensibilidade
}

\author{
Communication and sensibility
}

\section{Luiz Maurício Bentim da Rocha Menezes}

Mestre pelo Programa de Pós-Graduação em Lógica e Metafísica (PPGLM/UFRJ), Graduado em Filosofia pela Universidade Federal do Rio de Janeiro (UFRJ), Licenciado em Filosofia pela Universidade Federal do Rio de Janeiro (UFRJ), Graduado em Comunicação Social - Faculdades Integradas Hélio Alonso (FACHA), Doutorando do Programa de Pós-Graduação em Lógica e Metafísica da Universidade Federal do Rio de Janeiro (PPGLM/UFRJ), Rio de Janeiro, RJ - Brasil, e-mail: lmbrmenezes@yahoo.com.br

\section{Resumo}

Defendemos com este trabalho que, no ato de comunicar, é necessário muito mais do que uma linguagem estruturada, pois tal ato para se realizar, deve estar intimamente ligado às emoções. O Homem é um ser da linguagem, não podendo, desta forma, escapar a ela. No entanto, existe uma necessidade frequente nele de expressar aquilo que sente, e esta não consegue ser suprida somente por meio da linguagem. O Amor é um destes fortes sentimentos que move o Homem para comunicar, numa necessidade de atingir algo para além das palavras. Para complementar nosso estudo, efetuamos uma análise de alguns poemas de Alberto Caeiro, que, nas suas diferenças, consegue falar desse profundo e complicado sentimento.

Palavras-chave: Comunicação. Sentimento. Amor.

\section{Abstract}

This work claims that in the act of communication, much more than a structured language is necessary, since this act would be intimately connected to the emotions. Man is a being of language, who cannot escape from that. On the other hand, he often needs to express what he feels but can't fulfill this need through the language. Love is one of those strong feelings that move Man to communicate, in a pursuit to achieve something beyond words. Alberto Caeiro's poems 
were used as a guide to complement this analysis and with their differences he attempts to talk about that profound and complex feeling, which is Love.

Keywords: Communication. Feeling. Love.

"E tudo o que se sente diretamente traz palavras suas." Alberto Caeiro

\section{Introdução}

Há, no mundo, algo como uma falsidade comunicacional. Muito se fala da comunicação, muito se diz da sua expansão, quando, na verdade ela não ocorre. Apesar de todos os meios difusores de sinais, como jornais, revistas, publicidade, fax, celular, internet, entre outros, nenhum deles, de fato, efetiva o ato da comunicação. Esse excesso acaba por tornar a mensagem redundante e, desta forma, nada diferente passa ao seu receptor. Há uma ideologia de consumo, que torna o comunicar um imperativo, uma ordem, sem nenhuma capacidade de questionamento, numa verdadeira massificação de opiniões.

Noprefácio de seu livro, Understanding Media, McLuhan nos alerta para a projeção da consciência a partir da expansão do meio tecnológico, mantendo, no entanto, a questão aberta se as consequências disso são boas ou más. Quase meio século depois de sua primeira publicação, cabe a nós analisar parte desses efeitos. "Os meios têm o poder de impor seus pressupostos e sua própria adoção aos incautos" (MCLUHAN, 1974, p. 30). Numa sociedade de massa que utiliza os mesmos meios, passam pelos mesmos lugares, compram as mesmas coisas e vibram as mesmas festividades, pouco se comunica. As pessoas pronunciam-se apenas pela repetição, sempre as mesmas falas, tornam-se mudas, cegas e surdas, fechadas num mundinho só, incomunicáveis. A solidão existente de uma pessoa, cercada por diversas outras solidões, numa completa incomunicabilidade entre elas. Como nos mostra Gabriel García Márquez, em seu livro Cem Anos de Solidão, a solidão está nas diversas relações entre os homens, sejam elas de amor, ódio, paixão ou amizade. Ela está presente até mesmo quando parecemos rodeados por várias pessoas, numa verdadeira solidão partilhada. A comunicação não é algo facilmente realizável; ela exige situações particulares, talvez até mesmo íntimas, de captar (e sentir), aquilo que o outro tenta nos transmitir.
É aqui que se deve dividir a comunicação em dois pontos a serem estudados. O primeiro é o usual, aquele para todos colocados: há comunicação na mera difusão de um sinal. O segundo é: não há comunicação efetiva enquanto nosso sentimento continuar intransmissível. Analisaremos cada um desses pontos de vista a fim de justificar a nossa conclusão quanto ao processo comunicacional.

\section{I}

Do primeiro, pode-se colocar o velho sistema da comunicação: há um emissor (Z1) que transmite uma mensagem por um canal; esta é interpretada por um receptor (Z2) e daí surge o sentido (Z3). Essa é a dita relação intersubjetiva entre os seres. Até aí não há nenhum problema ou novidade. A transmissão de um sentido não depende apenas do que fala, e nem de quem recebe, mas da relação entre os dois, criando o entendimento, que não é algo profundo que penetra nas ideias ou sentimentos do outro, mas uma mera condição técnica para continuar a conversar. A língua, aqui, é utilizada apenas como informação e nada mais faz do que transmitir informação. "É precisamente esta concepção corrente da língua que se vê não somente avivada pelo fato da dominação da técnica moderna, mas reforçada e levada exclusivamente ao extremo" (HEIDEGGER, 1995, p. 33).

Aqui começa nosso problema. Num mundo em que os meios de comunicação atingem milhares de pessoas de uma só vez, não há troca nenhuma entre elas. Apenas há imposição de sinais vinda dos meios, sobre aqueles que recebem. A mensagem é o próprio meio, repetindo o que se é dito, independente de se usarem outras palavras, cujo contexto será sempre o mesmo. O processo também pode ser visto pela ótica da superinformação, que, na tentativa de informar, acaba por ocultar-nos o que deve ser conhecido, 
pois "o excesso abafa a informação quando estamos sujeitos ao rebentar ininterrupto de acontecimentos sobre os quais não podemos meditar porque são logo substituídos por outros" (MORIN, 1986, p. 31). Dessa relação macro do mundo, pode-se colocar as relações micro. As pessoas, ao se falarem, não dizem mais do que o comum, as mesmas frases, as mesmas falas. A conversa se torna uma coisa maçante, que transforma as relações entre os indivíduos cada vez mais medíocres. Um ruído se instala no diálogo, não há mais o que se passar ao outro, e, neste caso, o ruído é a redundância. A mensagem do "eu" não chega ao outro, justamente por utilizarmo-nos cada vez mais das mesmas falas. Torno-me incomunicável apesar de estar o tempo todo tentando me comunicar. Assim dão-se as relações no mundo, cada vez mais o dito diz cada vez menos. "Quem quer que seja pode falar sem cessar e a sua palavra não dizer nada. Um silêncio, pelo contrário, pode dizer muita coisa" (HEIDEGGER, 1995, p. 34).

Os veículos de comunicação massificaram todas as relações entre pessoas. Tudo já está programado, não há mais o que se dizer. O solipsismo foi instalado e com ele o fim da relação de troca entre os homens. Não existe mais o sentir, pois este já está pré-determinado pela sociedade. $\mathrm{O}$ que sentimos se tornou algo traduzível pela linguagem, imóvel. Os sentimentos, algo individual, em constante mudança, tornaram-se palavras fixas e determinadas. Constatamos um medo de sentir, de expor aquilo que se sente, uma coerção ao sentimento. É nesse medo de dizer ao outro o que realmente se sente, que nos impedimos de comunicar; é onde se instala o ruído que impede transmitirmos ao outro o nosso interior, algo verdadeiramente entrópico e original.

Nossas palavras mestras estão doentes: degradaram-se, tornaram-se obsessivas, são usadas a torto e a direito, pretendem conhecer tudo e explicar tudo. Perderam em virtude operacional e ganharam em virtude mágica de exaltação ou de exorcismo. Foram substancializadas, reificadas, tomaram o lugar das coisas que tinham por função designar.

$[\ldots]$

Nossas palavras mestras tornaram-se esburacadas, cegas e cegantes. Pensávamos que iluminavam a natureza da realidade social e política; descobrimos que a camuflavam (MORIN, 1986, p. 69).
Para que haja troca, é preciso que se consiga vencer a barreira imposta pela redundância, em que seja possível transmitir não só palavras, mas também sentimentos. $\mathrm{O}$ pensamento se torna uno com o sentir, e o sentimento se torna uno com o pensar, e não uma formação imposta por outros. Somente assim, as palavras trarão um sentido seu no mundo e um verdadeiro significado ao seu receptor. Uma língua que só transmite informação se torna vazia e muito pouco comunicativa.

É porque se desenvolve em sistemas de mensagens e de sinalizações formais que a língua técnica é a agressão mais violenta e mais perigosa contra o caráter próprio da língua, o dizer como mostrar e fazer aparecer o presente e o ausente, a realidade no sentido mais lato (HEIDEGGER, 1995, p. 37).

É essa língua técnica, que já nasceu morta na sua vontade de se fazer presente, de comunicar algo ao outro, totalmente ausente de expressão, que queremos criticar neste trabalho. Eserá na formulação dessa crítica que construiremos o nosso discurso, com o intuito de defender uma nova maneira de comunicar, a partir da reformulação do próprio meio em que se dá a comunicação: o discurso.

\section{II}

Devemos agora apresentar o segundo ponto da comunicação. É nesse que dizemos que só há comunicação efetiva quando há transmissão de sentimentos. Nisto, é preciso que o emissor consiga transmitir o que sente, e o receptor esteja apto à recepção deste. Do contrário, não há como se ter a comunicação plena. Apenas pela língua técnica acabamos por tornar-nos prisioneiros da linguagem, e tudo deve antes passar por ela. Não há como se transmitir algo sem utilizar a palavra. A realidade da palavra é absorvida por sua função de signo. Toda relação social deve passar pela palavra, sendo ela a detentora da realidade do homem. Pensar isto é reduzir a língua apenas à produção de sinais, ao envio de mensagens. A palavra não é, no entanto, substituta dos signos ideológicos, ou dos gestos humanos, assim como ela não pode substituir o sentimento. Não existe um substituto verbal adequando para o sentir. 
"Negar isso conduz ao racionalismo e ao simplismo mais grosseiros" (BAKHTIN, 1999, p. 38).

O sentir veio antes da palavra. A partir do momento que o homem passou a falar, o indivíduo tornou-se nulo. Todo tipo de sentir, toda colocação do pensar passou a só existir por meio da palavra. Há um desaparecimento do homem em proveito da linguagem e ele passou a ser representado apenas como signo. A agressão que a língua técnica exerce sobre o caráter da língua é, na verdade, uma agressão contra a própria Essência do homem. O homem não é só um ser da palavra, mas é esta que permite que ele seja o que é. No entanto, a técnica tem uma necessidade de tornar a língua unívoca, pois é a partir dessa univocidade que é assegurada a possibilidade de uma comunicação certa e rápida. Cada tentativa de tornar a língua unívoca por meio de uma formalização num sistema de sinais, pressupõe o uso da língua natural.

A língua 'natural', quer dizer, a língua que não foi por princípio inventada e imposta pela técnica, é sempre conservada e permanece, por assim dizer, como pano-de-fundo de toda a transformação técnica (HEIDEGGER, 1995, p. 40).

Essa língua nos é conhecida por língua da tradição (HEIDEGGER, 1995, p. 40). A tradição aqui apresentada não é uma negação do ser falante que é o homem, pois, "é enquanto ser falante que o homem é homem” (HEIDEGGER, 1995, p. 30), mas deixa claro que pela sua condição inerente à fala, toda e qualquer relação com ela irá afetá-lo diretamente. Cabe à tradição outra apresentação do mundo para que aí se chegue ao aparecer do ainda-não-apercebido, que nos permita um novo contato com as palavras, numa outra maneira de ser. "Ora eis aqui a missão dos poetas" (HEIDEGGER, 1995, p. 40). É pensando nisso que colocamos o poema XLVI do Guardador de Rebanhos, de Alberto Caeiro, heterônimo de Fernando Pessoa.

\section{XLVI}

Deste modo ou daquele modo,

Conforme calha ou não calha,

Podendo às vezes dizer o que penso,

E outras vezes dizendo-o mal e com misturas,

Vou escrevendo os meus versos sem querer,

Como se escrever não fosse uma cousa feita de gestos,
Como se escrever fosse uma cousa que me acontecesse Como dar-me o sol de fora.

Procuro dizer o que sinto

Sem pensar em que o sinto.

Procuro encostar as palavras à ideia

E não precisar dum corredor

Do pensamento para as palavras.

Nem sempre consigo sentir o que sei que devo sentir. O meu pensamento só muito devagar atravessa o rio a nado Porque lhe pesa o fato que os homens o fizeram usar.

Procuro despir-me do que aprendi, Procuro esquecer-medo modo de lembrarquemeensinaram, E raspar a tinta com que me pintaram os sentidos, Desencaixotar as minhas emoções verdadeiras, Desembrulhar-me e ser eu, não Alberto Caeiro, Mas um animal humano que a Natureza produziu.

E assim escrevo, querendo sentir a Natureza, nem sequer como um homem,

Mas como quem sente a Natureza, e mais nada.

$\mathrm{E}$ assim escrevo, ora bem, ora mal,

Ora acertando com o que quero dizer, ora errando,

Caindo aqui, levantando-me acolá,

Mas indo sempre no meu caminho como um cego teimoso.

Ainda assim, sou alguém.

Sou o Descobridor da Natureza.

Sou o Argonauta das sensações verdadeiras.

Trago ao Universo um novo Universo

Porque trago ao Universo ele-próprio.

Isto sinto e isto escrevo

Perfeitamente sabedor e sem que não veja

Que são cinco horas do amanhecer

E que o sol, que ainda não mostrou a cabeça

Por cima do muro do horizonte,

Ainda assim já se lhe veem as pontas dos dedos

Agarrando o cimo do muro

Do horizonte cheio de montes baixos (PESSOA, 2005, p. 72-3).

Podemos constatar, neste poema, a palavra como uma manifestação direta do sentir. Numa forma simples, sem precisar do pensamento, que tanto está condicionado pela sociedade, como corredor para se expressar, Caeiro expressa a sua crítica ao esquema 
mental que está entre a Natureza e seu próprio sentir, que impede que ele se realize, não como um homem qualquer, mas como quem sente a Natureza, e mais nada. Caeiro, que em tantos outros poemas exaltou a visão como uma necessidade, admite aqui o cego como um caminho correto a ser seguido. O cego aparece como aquele que não aceita o que de imediato lhe aparece, mas é aquele que vai experimentando por outras formas. O cego não aparece numa relação direta de não ver, mas para demonstrar que um caminho não deve ser percorrido de uma só maneira. Um cego que, no seu tatear, ensina que existem outras formas de ver, de sentir o mundo. Caeiro, com sua exaltação das sensações, nos oferece uma outra forma para a palavra, que não passa necessariamente pelo pensamento. Ele não nega a palavra como algo inerente ao homem, mas apenas nos dá a possibilidade de usá-la de maneira diferente. A ideia aqui não aparece como uma manifestação do pensar, mas antes do sentir. Com isto, Caeiro nos mostra o quanto nossa maneira de pensar é induzida, o quanto nossos sentimentos, antes mesmo de podermos senti-los, são construídos e fixados pelo pensamento. Um pensamento que não é nosso, mas de alguém que nos apresentou a ele.

A ideologia traduz o mundo em ideias e, por isso, interpõe-se entre o mundo e nós no momento em que realiza a comunicação. Somos vítimas da ideologia quando ignoramos que vemos o mundo por intermédio de nossas ideias e quando acreditamos ver o mundo em nossas ideias (MORIN, 1986, p. 70).

E por isso mesmo, nossa relação com o mundo se passa de maneira mais lenta, pois exige a palavra como um intermediário, o que seria diferente se fosse feita pelas sensações apenas, já que passaria diretamente. É para combater essa fixação do pensar que Caeiro vai defender o desaprender, a mudança da maneira de ver o mundo, mesmo que precisemos nos tornarcegos, pois essa cegueira nos possibilitarávermuitas outras coisas, tornando aqueles que veem os verdadeiros cegos do mundo. As emoções verdadeiras, estas sim, nos são próprias. É por meio delas que Caeiro nos propõe uma outra maneira de falar, que permita ao homem se relacionar diretamente com o mundo em que vive.

Veré assistir de dentro de nós à ruptura, à fissão do mundo, e reencontrar todos os aspectos do ser, como se este se duplicasse sobre si mesmo, fechando-se sobre um de seus pontos, com a interioridade voltada à exterioridade e vice-versa. Interioridade que sente e exterioridade sentida abrindo-se ambas, uma à outra, sem ruptura ao longo desta emenda que é o ser no mundo (MARCONDES FILHO, 2004, p. 80).

É pela necessidade de expressar suas paixões que o homem é levado à razão, a querer colocar o que se sente em palavras. Não é a existência da palavra que permite expressar o que sentimos, mas é antes o sentimento em seu sentido pré-linguístico que nos leva a falar. A palavra vem nos remeter às nossas experiências vividas e não para apresentar a experimentação delas.

[...] o entendimento humano deve muito às paixões, que, segundo uma opinião geral, the devem muito também: é pela sua atividade que nossa razão se aperfeiçoa; só buscamos conhecer por desejarmos usufruir, não sendo possível conceber por que aquele que não tivesse desejos nem temores se daria o trabalho de raciocinar. As paixões, por sua vez, originam-se de nossas necessidades, e seu progresso em nossos conhecimentos, pois só se pode desejar ou temer as coisas conforme as ideias que se pode ter delas, ou pelo mero impulso da natureza (ROUSSEAU, 2002, p. 175).

A linguagem modifica de acordo como experimentamos o mundo. Ela não se reduz a mera transposição do mundo em signos como quer a linguística, mantendo-se no plano de uma realidade esquemática e arbitrária. Tal realidade só tende a caminhar para o indizível, pois

[...] esse mundo em que tudo é signo e linguagem é o mundológico, instituído, jogo de convenções que existe, em realidade, para encobrirum outro, sutil, indireto, sub-reptício, pouco conhecido e explorado, ambiente de ar rarefeito em que a comunicação tenta sobreviver apesar de tudo (MARCONDES FILHO, 2004, p. 72).

A comunicação seria muito mais extensa e genérica do que a linguística; e a língua é apenas uma de suas manifestações. Segundo o dicionário 
de comunicação, a linguagem é "qualquer sistema de signos (não só vocais ou escritos, como também visuais, fisionômicos, sonoros, gestuais etc.) capaz de servir à comunicação entre os indivíduos" (BARBOSA; RABAÇA, 2001, p. 430). Ou seja, há uma servidão da linguagem à comunicação e não o contrário. No contexto presente, não conseguimos alcançar as outras pessoas, nem passamos o que sentimos, pensamos ou vivemos. Em suma, tornamo-nos incomunicáveis. "Sem dúvida, incomunicáveis para a língua disponível. [...] A linguagem é na verdade muito mais ampla, mais complexa, mais profunda do que pretende a vã linguística" (MARCONDES FILHO, 2004, p. 72). Ela não é um simples meio ou instrumento, mas se dá numa relação viva com o mundo, no qual o interior se encontra com o exterior, a subjetividade se encontra expressa na objetividade, onde eu sinto a presença do outro em mim e de mim no outro. No entanto,

há tantas coisas que sente e as palavras são tão pobres, estão aquém, infinitamente aquém da tradução de todo esse mundo interior. As palavras só repassam um rastro, uma imagem apagadiça do que sentimos e pensamos (MARCONDES FILHO, 2004, p. 95).

Se pegarmos como exemplo o corpo, veremos uma situação dúbia. Ele passa (ao mesmo tempo) aquilo que nós não queremos passar, como aquilo que queremos, mas não sabemos se de fato conseguimos. É o que Marcondes Filho (2004, p. 96) chama de Paradoxo da Comunicação. Segundo diz, existe a comunicação formal, que seria teatral, masculina, viciada e pobre, pois trabalha com a linguagem sígnica, significante e convencional; e também existe a comunicação real, que teria uma sensibilidade feminina para captar a fala não linguística da expressão do outro.

O signo não pode transmitir tudo que ocorre no real. Implica inclusive em diferenças culturais. Em determinadas línguas, existem palavras únicas para explicar algo, não encontradas em nenhuma outra língua e vice-versa. Um bom exemplo é a palavra saudade, do Português: "saudade" é algo muito maior do que um simples "miss you", do Inglês. Mas somente pela utilização de palavras não há como captar o seu total sentido, pois "saudade" sempre parecerá ser algo maior do que "miss you". No entanto, se pegarmos como exemplo duas pessoas que há tempos não se veem, numa situação de reencontro e primeiramente ao se abraçarem dizem: "Senti saudade", perceberemos o mesmo quando dizem: "I missed you", porque existe todo um sentimento que vai além da colocação de um signo, e por mais que "saudade" pareça maior que "miss you", em nada se diferencia nesse tipo de encontro de pessoas. $\mathrm{O}$ importante, no caso, não é o que eu digo ou de que forma minha ação será representada, mas sim o que eu sinto. Essa seria uma incapacidade do signo, uma incapacidade de tentar representar de forma total um sentimento. Deve-se, portanto, admitir uma falha da linguagem na tentativa de subordinar a comunicação a ela. A comunicação implica algo muito além da linguagem.

Esse "algo além" seria a busca de um processo efetivo de transmissão, em que não apenas se emitam sinais, mas que sinta-se efetivamente o outro, participemos com ele num mundo único que captem-se sentidos exclusivos e irrepetíveis. Para isso, é preciso entender que a comunicação humana serve-se tanto do que possuímos de explícito comotambém do implícito.

Ela não funde duas pessoas numa só, pois é impossível que o outro me veja a partir do meu interior, mas é o fato de ambos participarem de um mesmo e único mundo no qual entram e que neles também entra (MARCONDES FILHO, 2004, p. 15).

Para isso, é preciso mudar a visão que temos perante as coisas, em que o racionalismo pragmático impera sobre as atitudes do homem, e as discussões linguísticas transferem-se para uma linguagem ordinária. Nele o queimporta são os resultados comprovados pela ocorrência prática, em que podemos conceber efeitos experimentais da linguagem. O homem torna-seapenas pensamento, e este só é possível em signos, operando num universo tautológico de signos que só remetem a signos. O pragmatismo tem o vício de tender para manuais e o uso prático da linguagem que, sem nenhum fim maior, é um dos fatores para o esvaziamento desta, o que auxilia a tamanha incomunicabilidade existente.

Não se começou raciocinando, mas sentindo. [...] Todas as paixões aproximam os homens, que a necessidade de procurar viver força a separarem-se. Não é a fome, a sede, mas o amor, o ódio, a piedade, a cólera, que lhes arrancaram as primeiras vozes (ROSSEAU, 1983, p. 163-4). 
E é na defesa desses sentimentos, vistos normalmente de forma secundária, que escrevemos. As paixões, as emoções e tudo mais que vem do sentir foi o que deu origem à palavra. Esta, assim como o nome de tudo que viemos a conhecer, não existiria se não fosse em virtude dos sentimentos. Comunicar é algo que parte da alma, e por isso mesmo implica num conhecimento desta. Tomamos como alma aqui, isto que nos move a conhecer e principalmente a sentir e, por isso, todo discurso que pretende a comunicação deve conhecer a alma, partindo de um conhecimento de si para que, assim, possa conhecer os outros, e conseguir aproximar o seu sentir da capacidade de captar dos demais. O questionamento e a vontade de buscar algo interior liberta para uma investigação exterior, que nos leva a comunicar numa relação psicagógica ${ }^{1}$, seja ela feita por meio do diálogo como também da escrita, pois ambos, cada um a sua maneira, nos são tentativas de passar aquilo que sentimos, e poder, com isso, fazer outros compartilharem desse sentimento.

Há um momento no processo comunicacional em que há o estalo, há o impacto de quem constata o 'a-ha', um momento em que o outro enfim percebe, sente o que estou dizendo, entende, vive como eu, complementa o que eu dizia, participa desse mesmo mundo. Somos arrebatados, misturamo-nos no outro. Operou-se aí uma mudança qualitativa em nós, fomos comunicados (MARCONDES FILHO, 2004, p. 100).

Acreditamos que um desses momentos se dá no amor. Não qualquer tipo de amor, mas aquele que permite num encontro de casais também um encontro de almas. Aquele que, quando estamos afastados do amado, nos leva a sentir sua ausência, e nos momentos que estamos juntos é como se estivéssemos completos. É esse amor que nos leva a querer comunicar, mesmo que não seja por meio da palavra, mas sem deixar de fazê-lo. E para complementar isso colocamos o poema V do Pastor Amoroso.

V

O amor é uma companhia.

Já não sei andar só pelos caminhos, Porque já não posso andar só.
Um pensamento visível faz-me andar mais depressa E ver menos, e ao mesmo tempo gostar de ir vendo tudo. Mesmo a ausência dela é uma coisa que está comigo. E eu gosto tanto dela que não sei como a desejar. Se a não vejo, imagino-a e sou forte como as árvores altas. Mas se a vejo tremo, não sei o que é feito do que sinto na ausência dela.

Todo eu sou qualquer força que me abandona.

Toda realidade olha para mim como um girassol com a cara dela no meio (PESSOA, 2005, p. 82).

Nesse poema, percebemos a elevação do amor como uma busca por algo que nos satisfaça, por algo que nos acompanha mesmo na ausência do amado. Quando se está sozinho a caminhar pelos cantos, logo se pensa naquele que se ama; e se não tem a presença do amado, pelo menos tem-se sua companhia na ausência, já que o que antes era preenchido com a presença passa a ser preenchido com a falta. A ausência torna-se presente na falta.

Éo amorque nos leva a sentir saudademesmo quando estamos apenas segundos afastados, pois a saudade não é algo que possamos medir. A saudade é imensurável: ou sentimos ou não sentimos. E isto nos faz querer comunicar o tempo todo, a dar voz ao que sentimos, mesmo que não seja por meio de palavras.

O amor, dizem, foi o inventor do desenho; pôde também inventar a palavra, porém com menor felicidade. Pouco satisfeito com ela, despreza-a; possui maneiras mais vivas para se exprimir. Quanto dizia a seu amante aquela que com tanto prazer traçava a sua sombra! Que sons poderia empregar para traduzir esse movimento do braço? (ROUSSEAU, 1983, p. 160).

Descrever cada detalhe que sentimos, cada impressão que o amado nos passa, como podemos expressar tudo isso? Quando se pensa no amado, nada mais conseguimos ver direito. Vê-se menos porque a imagem do amado ocupa tudo que se tem dentro de si, e isto remete também ao que vemos do exterior, já que todo desejo está voltado para o objeto que nos faz falta. Quando Caeiro nos diz: "Toda realidade olha para mim como um girassol com a cara dela no meio". O que ele quer dizer é como pensar na amada transforma a realidade a sua

1 A psycagogía é uma palavra grega que significa a condução da alma, isto é, sua persuasão. 
volta. O girassol, dizem, tem como característica virar para onde se encontrar o sol. Ao pensar na amada, tudo a sua volta perde o sentido e tudo passa apenas a significar ela. A partir do pensamento, a realidade toda torna-se ela, que passa a olhá-lo o tempo todo, como um girassol. Um momento de solidão indescritível, que tudo mais transforma no interior, que tem sua própria expressão de riqueza de detalhes. Nesse momento de solidão, tudo mais torna-se belo.

A solidão e a comunicação não devem ser os dois termos de uma alternativa, mas dois momentos de um único fenômeno, já que, de fato, outrem existe para mim. [...] É preciso que de alguma maneira a reflexão nos dê o irrefletido, pois, de outra maneira, nada teríamos a opor-lhe e ela não se tornaria problema para nós. Da mesma forma, é preciso que de alguma maneira minha experiência me dê outrem, já que, se ela não o fizesse, eu nem mesmo falaria de solidão e nem mesmo poderia declarar outrem inacessível. [...] O fenômeno central, que funda ao mesmo tempo a minha subjetividade e a minha transcendência em direção a outrem, consiste no fato de que sou dado a mim mesmo (MERLEAU-PONTY, 1994, p. 482).

É certo dizer que o "eu" já se encontra no mundo físico estabelecido de maneira social e cultural, no entanto o mesmo "eu" não se limita a tal mundo, encerrado como um objeto em uma caixa. A partir do momento que nossa subjetividade mudar a maneira de lidar com a objetividade, o contrário também ocorrerá. Essa é a verdadeira troca, a construção de uma relação intersubjetiva, em que o sujeito que sou relaciona-se plenamente com seu objeto e ambos participam do mesmo universo. Sendo assim, segundo entendemos, a comunicação pode se dar das seguintes maneiras:

i) Quando o emissor não transmite sentimento e o receptor não está apto a sentir. neste tipo, a comunicação não passa da mera estrutura técnica de sinais. Nada mais.

ii) Quando o emissor transmite sentimento $e$ o receptor não está apto a sentir. o emissor transmite a mensagem fazendo passar o que sente, e assim, conseguindo libertar-se da situação morta dos signos. No entanto, o receptor da mensagem não está apto a percebê-la.

iii) Quando o emissor não transmite sentimento e o receptor está apto a sentir. o emissor apenas emite uma mensagem vazia, no entanto seu receptorvai além percebendo profundidade das palavras vazias.

iv) Quando o emissor transmite sentimento $e$ o receptor está apto a sentir: aqui tem-se a Comunicação Plena. Emissor e receptor se ligam de tal forma que as palavras são construídas nessa união. Na formação do diálogo, o receptor recebe os pensamentos do emissor que tem como resultado o fazer pensar que nos é transmitido pelo receptor. A mensagem torna-se uma manifestação do sentir.

É nesse processo que, de fato, nos comunicamos. Numa interação das consciências, em que as palavras vão além das aparências, conseguindo interagir com o sentimento e passando-os para o exterior numa reordenação do discurso. Agora, para que haja comunicação precisamos estar aptos a transpor as barreiras que separam a subjetividade da objetividade, na construção de uma comunicação transcendental do sujeito com seu objeto ao proferir o seu discurso, pois o discurso é o próprio meio que temos para realizar essa completa expressão do sentir. Comunicamo-nos quando o mais profundo interior de nós liberta-se e faz-se expressar para o mundo, e o mundo em troca nos faz pensar. É o que podemos perceber na interação que Caeiro nos passa do poeta interagindo com a realidade, quando esta passa a tocá-lo como o olhar do girassol que ao mesmo tempo é móvel por acompanhar o sol, mas torna-se fixo por escolher apenas o sol para acompanhar. O que demonstra a capacidade que a subjetividade tem de transcender aquilo que nos é simplesmente dado e, assim, atingir outrem de alguma outra maneira.

\section{Referências}

BAKHTIN, M. Marxismo e filosofia da linguagem. São Paulo: Hucitec, 1999. 
BARBOSA, G. G.; RABAÇA, C. A. Dicionário de comunicação. 2. ed. Rio de Janeiro: Câmpus, 2001.

HEIDEGGER , M. Língua de tradição e língua técnica. Tradução de Mário Botas do Original: Langue de Tadition et Langue Technique. Lisboa: Vega, 1995.

MARCONDES FILHO, C. Até que ponto, de fato, nos comunicamos? São Paulo: Paulus, 2004.

MCLUHAN, M. Os meios de comunicação como extensões do homem. Tradução de Décio Pignatari. São Paulo: Cultrix, 1964/1974. (Understanding Media).

MORIN, E. Para sair do século XX. Tradução de Vera Azambuja Harvey. Rio de Janeiro: Nova Fronteira, 1986.
PESSOA, F. Poesia completa de Alberto Caeiro. Edição de Fernando Cabral Martins e Richard Zenith. São Paulo: Companhia de Bolso; Companhia das Letras, 2005.

ROUSSEAU, J.-J. Ensaio sobre a origem das línguas. Tradução de Lourdes Santos Machado. 3. ed. São Paulo: Abril Cultural, 1983.

ROUSSEAU, J.-J. Discurso sobre a origem e os fundamentos da desigualdade entre os homens. Tradução de Maria Ermantina Galvão. São Paulo: M. Fontes, 2002.

Recebido: 16/01/2012 Received: 01/16/2012

Aprovado: 02/04/2012 Approved: 04/02/2012 
